\title{
TEACHING AIDS FOR TEACHING ABOUT ELECTRICITY
}

\section{Jakub DOSOUDIL}

\begin{abstract}
An integral part of technology in elementary schools is the area of physics and practical activities. There is currently possible to teach topics related to electricity. Since the laws of electricity and its related discipline the uneasy rather abstract phenomenon, to which the students can't touch, you need to use in the classroom the teaching aids. Without teaching aids students would be hard to understand topics. In this article we aim to compare of all the options the use of teaching aids, utilities compare themselves, evaluate their pros and cons and choose the best ones.
\end{abstract}

Key words: teaching aids, physics, electricity

\section{ŠKOLNÍ POMŮCKY PŘI VÝUCE O ELEKTŘINĚ}

Resumé: Neodmyslitelnou součástí techniky na základních školách je oblast fyziky a praktických činností. Právě zde je možné vyučovat témata spojená s elektrrinou. Jelikož je elektřina a zákonitosti s ní spojené nelehkou disciplínou a spíše abstraktním jevem, na který si žáci nemohou sáhnout, je potřeba ve výuce používat školní pomůcky. Bez školních pomůcek by těžko žáci témata pochopili. V našem článku si položíme za cíl porovnat všechny dostupné možnosti využití školních pomůcek, samotné pomůcky porovnat, zhodnotit jejich klady a zápory a zvolit ty nejlepší.

Klíčová slova: školní pomůcky, fyzika, elektřina.

\section{1 Úvod}

Otázka volby školních pomůcek je jednou z nejdůležitějších, kterou musí jak učitel daného předmětu, tak i ředitel $\mathrm{v}$ rámci celé školy udělat. $\mathrm{V}$ dnešní době nedostatku finančních prostředků ve školství je velice složité do výuky dostat přesně ty pomůcky, které si výuka vyžaduje, a které by učitel rád $\mathrm{v}$ hodinách použil. Kdyby totiž nemusel nahlížet na finanční stránku, mohl by vybrat pro děti tu nejvhodnější pomůcku, tzn. tu která je bude nejvíce zajímat, která ponese nejvyšší edukační potenciál a se kterou se žákům bude nejlépe pracovat. Na trhu školních pomůcek je spousta zajímavých a edukačně prínosných věcí, které by značně pomohly zefektivnit výuku všech předmětů, nejen fyziky a praktických činností a pomohly by dosáhnout výukových cílů rychleji a snadněji. V tomto článku porovnáme některé dostupné školní pomůcky, které lze v předmětech Fyzika a Praktické činnosti využít. Zhodnotíme jejich výhody a nevýhody a vybereme tu, která je pro výuku nejlepší.

\section{Definice materiálních a didaktických pomůcek}

Pojem materiální didaktické prostředky a pojem školní pomůcky nepojmenovávají jednu a tu samou věc. Nejprve si definujeme základní pojem materiální didaktické prostředky (MDP). „Za tyto prostředky je možné považovat v̌̌e, co kromě mluveného slova, použivá pedagog či žák ve vzdělávacim procesu, tedy prì primé pedagogické práci, nebo při řizeném samostudiu žákù. "(SLAVÍK Milan, 2007, s. 7).

Učební pomůcky jsou prostředky edukačního procesu, které svojí funkcí prrispívají k účinnějšímu dosahování cílů výuky. Je tedy jakýmsi nositelem informace, která má žáka vzdělávat (může to být model, mapa, obraz, hornina, stavebnice, atd.). Do této kategorie lze zařadit i didaktické programy neboli didaktický či multimediální software.

Nyní si také můžeme charakterizovat pojem didaktická technika. „Didaktická technika je soubor vizuálních, auditivních, audiovizuálních a jiných prístrojů a technických systémů využivaných $k$ vyučovacím účelìm." (SLAVÍK Milan, 2007, s. 9). Jedná se o zařízení, které jsou potřebné pro prezentaci učiva. (např. dataprojektor, počítač, zpětný projektor, atd.)

Použivání materiálních prostředků musí být dle profesora Slavíka učitelem promyšlené a didakticky odůvodněné. Pokud tomu tak bude, MDP mohou plnit několik funkcí, pro které jsou právě tak často zařazovány do výuky na ZŠ. Mezi nimi Slavík zmiňuje to, že aktivizují výuku a působí na žáky motivačně (2007, s. 9). Školní pomůcky mohou také uvolňovat atmosféru v hodině a podněcovat kreativitu žáka. 


\section{Učebnice a jiné tišstěné pomůcky do hodin}

Stejně jako se postupem času vyvíjí a mění výuka, mění se s ní i učebnice. Již se nesetkáme s učebnicí, která neobsahuje žádné obrázky, nebo která je plná souvislého textu a látku vysvětluje pouze výkladem. Dnešní učebnice fyziky a praktických činností, které se zaměřují na výuku elektřiny a všech zákonitostí s ní spojenými, jsou velmi pěkně ilustrované. Obsahují spoustu grafů a obrázků a jsou o dost efektivnějšś než jejich starší předchůdci. Obrázky a diagramy se $\mathrm{v}$ učebnicích snaží vysvětlit určité jevy a pochody, které mohou v elektrickém obvodu nebo v elektronickém př́stroji probíhat, ne vždy se jim to ale daří. I když jsou ilustrace velice dobře udělány a diagramy danou věc popisují nejlépe, jak je to na papíře vůbec možné, nikdy tato ilustrace nemůže nahradit reálné zapojení obvodu a zkoušku jeho funkčnosti. Existují také pracovní sešity z fyziky, které se snaží výuku aktivizovat, vysvětlit postup zapojení a funkci komponent $\mathrm{v}$ obvodu, stejně jako samotné zapojené obvody. Ty však neumožní žákovi si jednotlivé součástky, vodiče nebo měřící př́ístroje osahat a vyzkoušet si jejich funkci $v$ reálném čase. Tyto učebnice mají spoustu výhod, lze je hodnotit velmi kladně, ale při srovnání s ostatními pomůckami, které může učitel v hodině použít, v názornosti zaostávají. Lze je spíše využít v kombinaci se samotnými součástkami, nebo stavebnicemi.

\section{Improvizované pomůcky, jednotlivé součástky a dalš́i}

Pokud škola nemá dostatek financí na nákup pomůcek pro výuky o elektřině, tzn. elektrotechnických stavebnic nebo jednotlivých části měřícího či experimentálního obvodu, musí hledat jiná východiska, např. si pomůcky vyrobit. Improvizované pomůcky mohou vytvořit jak učitelé, tak samotní žáci jako součást pracovních činností. Součástky lze nakoupit za minimální náklady a pomocí malých dřívek a hřebíčků připevnit $\mathrm{k}$ sobě. Můžeme tak vytvořit jakousi improvizovanou elektrotechnickou stavebnici, kterou lze propojovat různě dlouhými vodiči (tento způsob byl využit napřr. ve škole Z Hlubočky v Olomouckém kraji). (2) I přesto, že vyrobená stavebnice plně neodpovídá bezpečnostním předpisům, pro malé proudy a jednoduchá zapojení se dá použít i v žákovských lavicích. Pro složitější zapojení může učitel obvod zapojit sám a pouze jeho funkci tř́dě demonstrovat. Samotná tvorba tohoto typu stavebnice může být velice prŕnosná pro žáky z hlediska posílení jejich kreativity a zručnosti. Lépe si pak uvědomí, kolik práce je zapotřebí pro vytvoření jednoduchého obvodu. Samožrejmě se součástky mohou propojovat i bez označených dřívek a hřebíčků pouhým spojením vodičů, ale tento způsob je dosti nepřehledný, nestabilní a může dojít ke ztrátě součástek malých rozměrů.

Improvizovaná stavebnice $\mathrm{s}$ dřívky a hřebíčky použita společně s učebnicí fyziky $v$ hodině je pak velice efektivní a žáci mnohem lépe pochopí učivo. Samotná stavebnice aktivizuje výuku natolik, že se učivo může stát pro žáky zábavnější a dopomůže snadnějšímu dosažení výukových cílů. Tato stavebnice ovšem má některé nevýhody, které také učitel musí zvážit, před jejím zavedením do výuky. Jak již bylo zmíněno, práce se stavebnicí není príliš bezpečná, a při neopatrném zacházení může dojít $\mathrm{k}$ menším poraněním, napřr. o odizolované vodiče nebo hřebíčky, kterými jsou vodiče k dřívkům upevněny. Pokud by se pracovalo s napětím malých tužkových baterií nebo monočlánků, k úrazům elektrickým proudem by nemohlo vůbec dojít. Stavebnice ale i tak může působit trochu nekompaktně, rozházeně a práce s ní může být zdlouhavá v porovnání se stavebnicí zakoupenou v obchodě. Stavebnice od firem dodávané do škol mají často velice dobře vyřešeno propojování komponent $\mathrm{v}$ obvodu, bud' banánkovými vodiči, nebo propojovacími poli. Proto je práce s nimi rychlejš́i, přehlednější a žáka nepřestane tak rychle bavit. Z hlediska finančních nákladi̊ je improvizovaná stavebnice jasnou volbou. Pokud má ale škola dostatek financí na pořízení klasických elektrotechnických stavebnic, pak se zřejmě přikloní k jejich nákupu, jelikož mají mnohem lepší vlastnosti.

\section{Elektrotechnické stavebnice jako celky}

Stavebnice se na dnešních školách ze všech školních pomůcek pro výuku o elektřině používají nejčastěji. Přsto nejsou zrovna v nejlepším stavu, jak uvádíme ve článku (2), kde byl proveden průzkum na několika základních školách a byl zjištěn stav užívání elektrotechnických stavebnic. Stavebnice byly velmi staré, okolo 20 let, někdy i více, chyběly jim některé součástky a pár $\mathrm{z}$ nich bylo nefunkčních. Pokud by ovšem byla tato stejná stavebnice zcela nová, kompletní, byla pro výuku velice př́nosná. Jednotlivé prvky byly totiž velice dobře konstruovány. Bylo jasné, co žák právě do obvodu zapojuje a jak má hotový obvod vypadat. Efektivnost práce s touto stavebnicí byla dobrá, ale při lepším stavu stavebnice by mohla být 
o dost větší. Hlavními výhodami stavebnic jsou především zpracování jednotlivých bloků stavebnice, možnost jejich rychlého zapojení a odpojení od obvodu, skladnost stavebnice, její názornost a někdy také barevné zpracování. Námi uvedené výhody jsou pouze základní, stavebnice jich má ovšem více.

Nově zakoupené stavebnice jsou doplněny o spoustu užitečných prvků, měřících přístrojů, motorů, diod, integrovaných obvodů, atd. Existují sady pro jednotlivá témata výuky fyziky, jako je magnetismus, elektrostatika, práce a výkon, elektromagnetismus, elektromagnetická indukce, atd. Tyto sady učiteli velice pomohou s vysvětlováním látky a žáci pak mnohem lépe a rychleji pochopí učivo. Moderní elektrotechnická stavebnice je pro výuku ve spojení s učebnicí fyziky zřejmě tou nejlepší volbou. Učitel a škola musí mít ale dostatek finančních prostředků na to, aby si tyto učební pomůcky mohla pořídit.

\section{Závěr}

Při srovnání námi zmíněných výukových pomůcek, které lze použít ve výuce o elektřině, můžeme vyvodit několik závěrů. Při vyučování hraje stále nepostradatelnou roli učebnice, ve které se soustřed'ují všechny potřebné informace a poznatky, které jsou zapotřebí $\mathrm{k}$ dosažení výukových cílů. Elektřina a magnetismus jsou ale natolik abstraktní pojmy, že je vždy při jejich výuce nutné použít něco víc než jen učebnici. Pro jednoduché vysvětlení základních obvodů, měřených veličin a funkcí součástek je velice užitečný i improvizovaný obvod z jednotlivých součástek. Tato volba je nejlepší, pokud nemá učitel dostatek financí na pořízení stavebnic od výrobců, poskytujících učební pomůcky. Navíc je dobré př́i výrobě bloků zapojit i žáky, kteří tak rozvinou svoji zručnost a šikovnost. Stále je ovšem při porovnání všech kladů a záporů pro výuku nejvhodnější použít zakoupené stavebnice. Rozhodování, kterou ze zmíněných učebních pomůcek ve výuce použít, není lehké. Každá z nich do výuky přináší něco jiného. Učebnice poznatky, výroba improvizované stavebnice kreativitu a zručnost pro žáky a zakoupená stavebnice vše, co školní pomůcka pro výuku o elektřině přinést musí. Nejlepším řešením by bylo zapojit do výuky všechny tyto pomůcky a plně tak využít potenciál každé z nich.

\section{Literatura}

[1] SLAVÍK, M., HUSA, J., MILLER, I. Materiálni didaktické prostředky a technologie jejich využivání. 1. vyd. Praha: ČZU v Praze, 2007, 50 s. ISBN 978-80-213-1705-5.

[2] DOSOUDIL, J. Elektrotechnické stavebnice ve výuce na 2 . stupni ZŠ. In Technológie $v z d e l a ́ v a n i a v$ príprave učitelov prírodovedných a technických predmetov. Sborník z mezinárodní konference $v$ Prešove. Prešov: Prešovská univerzita. 2011. s. 107 - 112. ISBN 978-80-5550438-4.

Lektoroval: Mgr. Magdalena Janků

Jakub Dosoudil, Mgr.,

Katedra technické a informační výchovy, Pedagogická fakulta UP,

Žižkovo nám. 5, 77140

Olomouc, $\check{C} \mathbf{R}$,

tel. +420 585635813 , e-mail: jakubdosoudil@seznam.cz Školitel: doc. Ing. Čestmír Serafín, Dr. IngPaed. 